\title{
Woody Species Structure and Regeneration Status in Kafta-Sheraro National Park Forest, Tigray Region, Ethiopia
}

\author{
Fitsum Temesgen $^{1 *}$, Bikila Warkineh ${ }^{2}$ \\ ${ }^{1}$ Addis Ababa University, Center of Environmental Sciences, Addis Ababa, Ethiopia \\ ${ }^{2}$ Addis Ababa University, Center of Environmental Sciences, Addis Ababa, Ethiopia \\ * Corresponding Author: fitsetee21@ gmail.com
}

\begin{abstract}
The natural vegetation study was conducted in Kafta-sheraro national park (KSNP) North, Ethiopia to explore floristic composition, structure and regeneration of woody species in the home of African elephant. In the park, the above information is not well documented which is necessary for conservation. Data were collected From August to December 2018. The vegetation data were collected from 161 quadrats of size $20 \mathrm{~m} \times 20 \mathrm{~m}, 5 \mathrm{mx} 5 \mathrm{~m}$ for shrub/tree, sapling and seedling respectively. Individual trees and shrubs $\mathrm{DBH}>=2.5 \mathrm{~cm}$ and height $>=2 \mathrm{~m}$ were measured using Tape meter and Clinometer respectively. DBH, frequency, density, basal area, and IVI were used for vegetation structure. A total of 70 woody species $46(65.7 \%)$ trees, $18(25.7 \%)$ shrubs and 6 $(8.6 \%)$ tree/shrub) were identified. The total basal area and density of $79.3 \mathrm{~m}^{2} \mathrm{ha}^{-1}$, and $466 \pm 12.8$ (S.E.) individuals $\mathrm{ha}^{-1}$ were calculated for 64 woody species. Fabaceae was the most dominant family occupied 16 species (23.0\%) followed by Combretaceae 8 species (11.4\%). Acacia mellifera and Combretum hartmannianum were the most dominant and frequent species. Abnormal patterns of selected woody species were dominantly identified. Regenerating status all the woody plant species was categorized as "Fair" (18.75\%), "Poor" (7.81\%) and "None" (73.44\%). However, there is good initiation for conservation of the park; still the vegetation of the park was threatened by firewood collection, charcoal production, fire, intensive farming, mining and over grazing. Therefore, the study area as the habitat for the population of the African elephant; the KSNP should be recommended the highest conservation priority and studied the soil seed bank of species having poor regeneration condition.
\end{abstract}

Key words: Kafta-sheraro national park; woody species structure; regeneration status

\section{Introduction}

Ethiopia is considered as one of the top twenty five biodiversity richest countries in the world (WCMC, 1994). It is estimated to around 6000 species of higher plants, of which about $10 \%$ 
endemic plants) (Ensermu and Sebsebe, 2014).The flora is very heterogeneous and has a rich endemic element owing to the diversity in climate, vegetation and terrain. While six endangered endemic plant species are found in Ethiopia especially in the Ogaden region of the ecosystem only, this is floristically the richest in endemism of species in the country (Ensermu et al., 1992).

Population structure is the distribution of individuals of each species in arbitrarily to provide the overall regeneration profile of the forest based on tree density, height, frequency, diameter at breast height, species importance value and basal area (Getachew et al., 2002; Shibru and Balcha, 2004). Examination of patterns of species population structure could provide valuable information about their regeneration and/or recruitment status as well as viability status of the population that could further be employed for devising evidence-based conservation and management strategies (Abiyou et al., 2011).

Regeneration is a central component of forest ecosystem dynamics and restoration of degraded forest lands. Sustainable forest utilization is only possible if adequate information on the regeneration dynamics and factors influencing important canopy tree species is available (Getachew et al., 2010). The regeneration status of species in a community can be accessed from the total population dynamics of seedlings and saplings in the forest community (Getachew et al., 2002; Duchok et al., 2005). The overall pattern of population dynamics of seedlings, saplings and adults of a plants species can exhibit the regeneration profile, which is used to determine their regeneration status (Tamrat, 1994). A population with sufficient number of seedlings and saplings depicts satisfactory regeneration behavior (Pokhriyal et al. 2010), while inadequate number of seedlings and saplings of the species in a forest indicates poor regeneration condition (Tripathi and Khan, 2007). Moreover, Regeneration status of a forest is poor if number of seedlings and saplings are much less than mature individuals (Kedir et al., 2015). The anthropogenic disturbances (illegal fire, over grazing, intensive farming and firewood collection) revealed high degradation of population structure and regeneration status of the trees in the studied forest ecosystem (Getaneh et al., 2019). Assessment of soil seed banks, seedling banks and population structure has some practical importance in forest conservation and management (Haileab et al., 2011).

Most of the vegetation resources of the world are concentrated in protected areas (IUCN, 1994).The country's protected areas, such as national parks are rich with distinctive flora and fauna 
(Yalden and Largen, 1992). Protected areas play a vital role in biodiversity conservation (Molla et al., 2010). However, the vegetation resources of Ethiopian protected area are being destroyed at an alarming rate, because of habitat degradation or loss, fragmentation due to livestock encroachment, illegal settlement, agricultural expansion, deforestation, burning of vegetation for cultivation and mining, land-use and border conflicts of local communities. Moreover, vegetation cover is being converted for subsistence and commercial agriculture, timber used for fuel wood and construction, protected grasslands used for livestock grazing, and wetland destruction leads to the decline of vegetation and vegetation resource (Malede and Girma, 2015; Getachew and Weldemariam, 2016 ).

Kafta-Sheraro National Park (KSNP) is a newly established as a park while formerly named Shire wildlife reserve in Tigray region which was established in 1965e.c (Source: information obtained from local informants). The park is rich in natural vegetation and great wildlife resources particularly the home of mega herbivores of African elephant. Therefore, for effective management and conservation of the park, there is an urgent need to develop a sound management plan, and this required detailed base line information on the general stand structure and seedling and sapling status of woody species. However, KSNP currently lacks scientific and essential base line information on vegetation that is fundamental for sustainable management and conservation of the park tree species. The aim of this study focused on stand structure and regeneration status of the woody species.

\section{Materials and Methods}

\subsection{Study Site}

Kafta-Shirero national park is located in Kafta-humera and Tahtay-adeyabo weredas of Western and North-western Zones of Tigray region 1356km far from Addis Ababa and 490km of Mekelle City. The park is situated in the northwest of Ethiopia between latitude $14^{0} 05^{\prime}-14^{0} 27^{\prime} \mathrm{N}$ and longitude $36^{0} 42^{\prime}-37^{0} 39^{\prime}$ E. The park bordered by Eritrea in the north through Tekeze River (Figure 1). The elevation of the park varies from 539 to 1130 m.a.s.l. The landforms of the areas are heterogeneous in nature and consist of flat plain, undulating to rolling, some isolated hills and ridges, chain of mountains and valleys. 


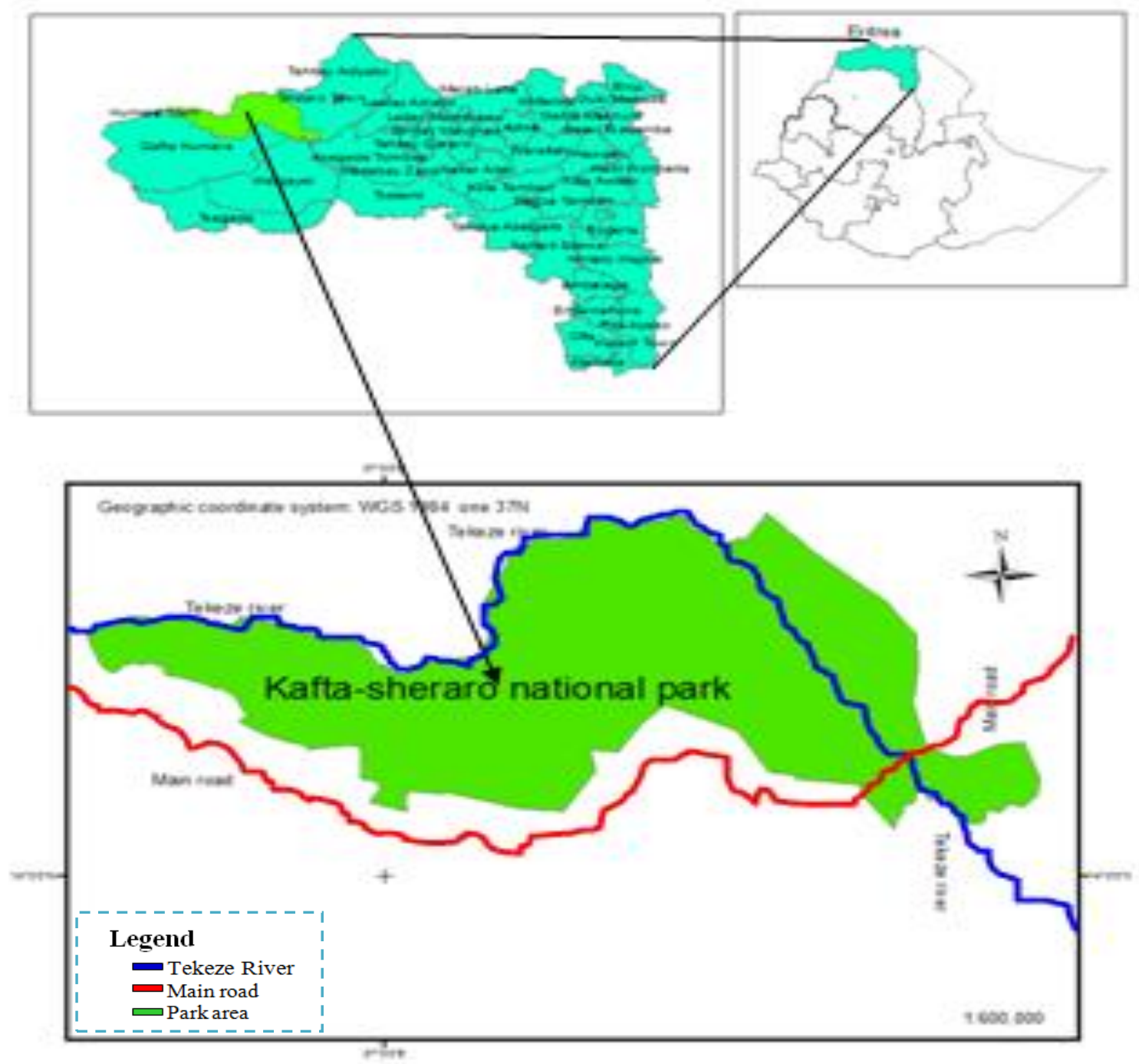

Figure 1: Location of the study site

Climate: The mean monthly temperature ranges from $28.35^{\circ} \mathrm{C}$ to $35.1^{\circ} \mathrm{C}$. The coolest temperatures occur from July to September while the warmest temperatures occur from March to May. The maximum mean monthly temperature ranges from March to May while the minimum ranges both in August and January, respectively. The rainfall pattern is bimodal with two distinct seasons. The short rains occur during May to mid June and September whereas the long rains occur during July and August. The nearby stations of Humera and shiraro district of meteorological center data (1966-2016) were used (Figure 2). 


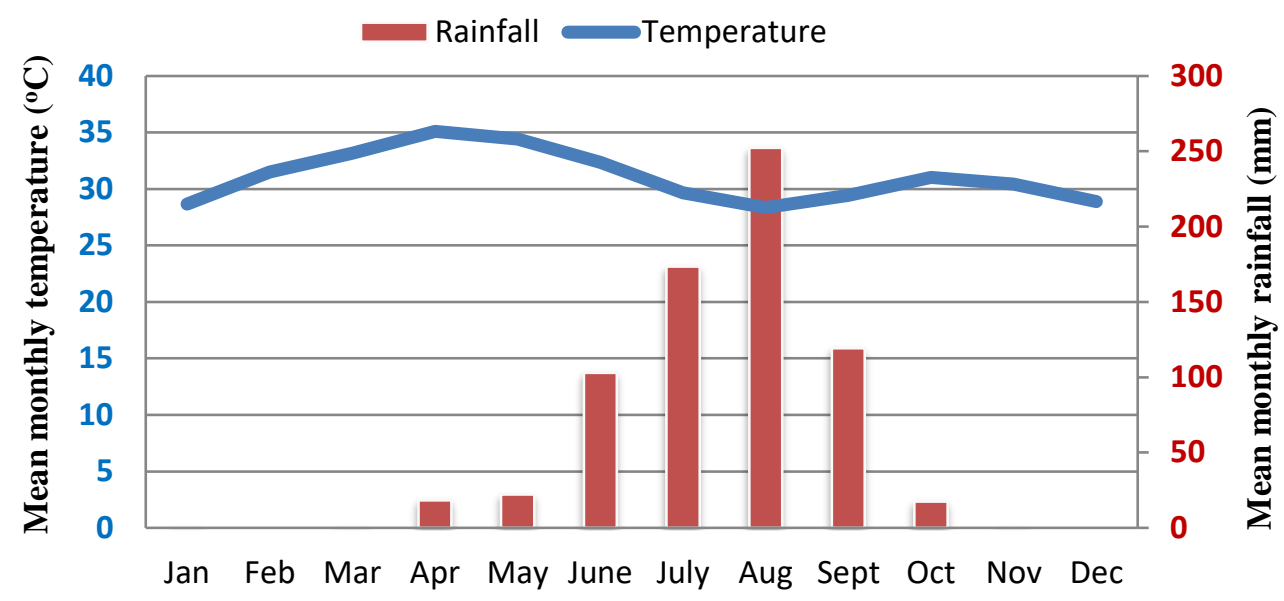

Figure 2: Mean monthly Rainfall and Temperature of Humera and Shiraro Meteorological Center from 1966-2016 (Ethiopian National Meteorological Agency, 2018)

\subsection{Sampling design}

A reconnaissance survey was taken from August, 18 to 25-2018 in order to have an impression of the forest sites and systematic sampling design was applied following (Kent and Coker, 1992). According to Cain, $(1959,1938)$ and McIntosh, (1985) species-area curve (minimal area) concept; the plot size was decided. Then a quadrats size of $20 \mathrm{mx} 20 \mathrm{~m}\left(400 \mathrm{~m}^{2}\right)$ were established along a line-transects following (Muller-Dombois and Ellenberg, 1974; Kumlachew and Tamrat, 2002; Getaneh et al., 2019). A total of 161 plots and adjacent 32 transects were placed at a distance of 200m and 300m apart respectively following (Kflay and Kitessa, 2014; Tiwari et al., 2010). All transects and plots located on the ground using compass and GPS navigation system.

\subsection{Data collection}

The detail vegetation data were collected during flowering and fruiting season from August, 2630 December, 2018. Trees and shrubs: In each the main sample plots $\left(400 \mathrm{~m}^{2}\right)$; individual plants (stems) of all tree and shrub species with diameter at breast height $(\mathrm{DBH}) \geq 2.5 \mathrm{~cm}$ abudndance were counted and recorded their circumferance (diameter). Height of individual trees and shrubs $\geq 2 \mathrm{~m}$ were recorded for every woody individual plants having $\mathrm{DBH}>=2.5 \mathrm{~cm}$ (Gemedo et al., 2006; Hasan et al., 2011; Tesfaye et al., 2017b). Diameter and height were measured using tape meter and clinometer respectively. Trees with multiple stems arising from the ground level were measured individually and developed a common DBH of all stems by summing up their square roots following (Brundrett et al., 1996). 
Sapling and seedlings: To collect data on abundance of sapling and seedling of each woody plant species, sub-plots of $5 \mathrm{~m} \mathrm{x} 5 \mathrm{~m}\left(25 \mathrm{~m}^{2}\right)$ were set up within the main plot. Height of each samplings and seedlings measured using tape meter. Saplings are young woody plants with $\mathrm{DBH}<2.5$ and height $>1 \mathrm{~m}<2 \mathrm{~m}$ where as seedlings as woody plants with $\mathrm{DBH}<2.5 \mathrm{~cm}$ and height $\leq 1 \mathrm{~m}$ (Chauhan et al., 2008a; Abyot et al., 2014).

Plant species identification: was started in the field by recording the local name through asking to local elders and referring the scientific name identification using Flora of Ethiopia and Eritrea Volume-1 toVolume-8 (Hedberg and Edwards, 1989; Edwards et al., 1995; Phillips, 1995; Edwards et al., 1997; Hedberg et al., 2003; Mesfin Tadesse, 2004; Hedberg et al., 2006, 2009a, 2009b). Specimens of identified and unidentified species were collected, pressed and dried properly, following standard Herbarium procedures, and taken to the National Herbarium (ETH) at Addis Ababa University for further confirmation and for identification of specimens of those species which could not be identified in the field.

\subsection{Data analysis}

\section{a. Woody species structure}

Diameter at breast height, height, basal area, tree density, frequency and important value index describes woody vegetation structure of a given forest. The following formula were utilized in Microsoft Excel spreadsheet programme and presented in descriptive statistics.

Diameter at breast height (DBH): diameter of woody species arbitrarily arranged in diameter class intervals by referring (Mligo, 2015; Tesfay et al., 2019). Diameter of trees/ shrub plant species of KSNP was classified into nine classes of 10cm interval (2.5-10,10.1-20, 20.1-30, 30.140, 40.1-50, 50.1-60, 60.1-70, 70.1-80 and >80.1cm).

Height: height of individuals' trees/shrub plant species were arbitrarily defined by height class intervals (Tesfaye et al., 2013; Ermias et al., 2010). Height of KSNP was classified into seven classes of $5 \mathrm{~m}$ interval $(<=4,4.1-9,9.1-14,14.1-19,19.1-24,24.1-29$ and $>29.1)$. The densities of individuals falling in the DBH or height classes were summed up.

Frequency of species: is defined as the probability or chance of finding a species in a given sample area (Kent and Coker, 1992).

Frequency $(\mathrm{F})=\left(\frac{\text { Number of plots in which a species occurs }}{\text { total number of plots laid out in the study site }}\right) \times 100$

Relative frequency $(\mathrm{RF})=\left(\frac{\text { frequency of a single species }}{\text { total frequency of all species }}\right) \times 100$ 
Finally frequency was summarized by class interval following Lamprecht (1989). The frequency of KSNP was arranged into seven classes of $15 \%$ intervals $(<=5,5.1-20,20.1-35,35.1-50$, 50.1-65, and 65.1-80 and $>80.1 \%$ ).

Density of species: is a count of the numbers of individuals of each species within the quadrat (Kent and Coker, 1992). The sum of individuals per species is analyzed in terms of species density ha $^{-1}$ (Mueller-Dombois \& Ellenberge, 1974; Martin, 1995).

$$
\begin{aligned}
& \text { Density (D) }=\frac{\text { number of aboveground stems of a species }}{\text { Number of quadrat } * \text { quadrat area }} \\
& \text { Relative density (RD) }=\frac{\text { Density of a single species }}{\text { Total density of all species }}
\end{aligned}
$$

Density was arranged by class intervals following (Tesfay et al., 2019) dry forest study. KSNP forest was classified in to five density class intervals: $<=2,2.1-10,10.1-50,50.1-100$ and $>100.1$ stems ha-1.

Basal area: is the area outline of a plant near ground surface and expressed in $\mathrm{m}^{2} \mathrm{ha}^{-1}$ (Kent and Coker, 1992; Martin, 1995).

Basal area $(\mathrm{BA})=\frac{\pi d^{2}}{4}$ Where, $\pi=3.14$ and $\mathrm{d}=\mathrm{DBH}(\mathrm{m})$

Dominance: the degree of coverage of species as an expression of the space at ground level

(Mueller-Dombois and Ellenberge, 1974)

Dominance $=$ the mean basal area per species $*$ abundance $($ no $)$ of the species

Relative dominance $(\mathrm{RDO})=\left(\frac{\text { dominance of a sinle species }}{\text { total dominance of all species }}\right) \times 100$

Importance Value Index (IVI): Indicating the relative ecological importance of a given woody species a particular site (Kent and Coker, 1992; Martin, 1995).

IVI= Relative density (RD) + Relative frequency (RF) + Relative dominance (RDO)

\section{b. Woody species regeneration}

The regeneration status of KSNP woody species was computed by comparing seedling and sapling with matured trees density data by applied (Khumbongmayum et al., 2006 ; Dhaulkhandi et al., 2008; Chauhan et al., 2008a; Chauhan et al., 2008b; Tiwari et al., 2010) techniques.

If seedling > sapling > mature tree ("good" regenerating); mature tree > sapling > seedling ("fair" regenerating); if a species survives only in the sapling stage ("poor" regenerating) (even saplings $<,>$, or = to mature); if a species is absent both in sapling and seedling stages but present as mature ("none" regenerating); if a species has no mature, but only sapling and/or seedling stages ("new" regenerating). 


\section{Result}

\subsection{Floristic Composition}

A total of 70 woody species belonging to 50 genera and 34 families were identified in Kaftasheraro national park (KSNP) forest. From these species, 46 (65.7\%) trees, 18 (25.7\%) shrub, 6 $(8.6 \%)$ tree/shrub. Fabaceae was the most dominant family occupied 16 species $(23.0 \%)$ followed by Combretaceae 8 species (11.4\%); Tiliaceae and Rhamnaceae 4 species (11.42\%); Capparaceae and Anacardiaceae 3 species each (8.58\%); Burseraceae, Ebenaceae, Asclepiadaceae and Apocynaceae 2 species each (11.44 \% from total) and the rest 24 families represented one species each (34.23\% from total species) (Appendix 1). Out of 70 species 64 were used for next analysis and six species were outside plots utilized for composition list only.

\subsection{Density and frequency}

The total density KSNP woody species was $466 \pm 12.8$ stems ha ${ }^{-1}$. Acacia mellifera was the most abundant species with abundance value of 446 individuals and a density of 69.7 stems ha $^{-1}$. Acacia mellifera, Combretum hartmannianum, Balanites aegyptiaca, Acacia oerfota, Boswellia papyrifera and Acacia Senegal were above 150 individuals while Dicrostachy scinerea and Combretum molle have densities 100 stems ha ${ }^{-1}$ and above. The relative density ranged between 0.03 and 15\%, the highest being for Acacia mellifera (Table 1). The woody species density was classified in to five class intervals: $<=2,2.1-10,10.1-50,50.1-100$ and $>100.1$ stems ha $^{-1} .48 .4 \%$ and 3.13\% species occupied density class $<=2$ and 50.1-100 respectively (Figure 3).

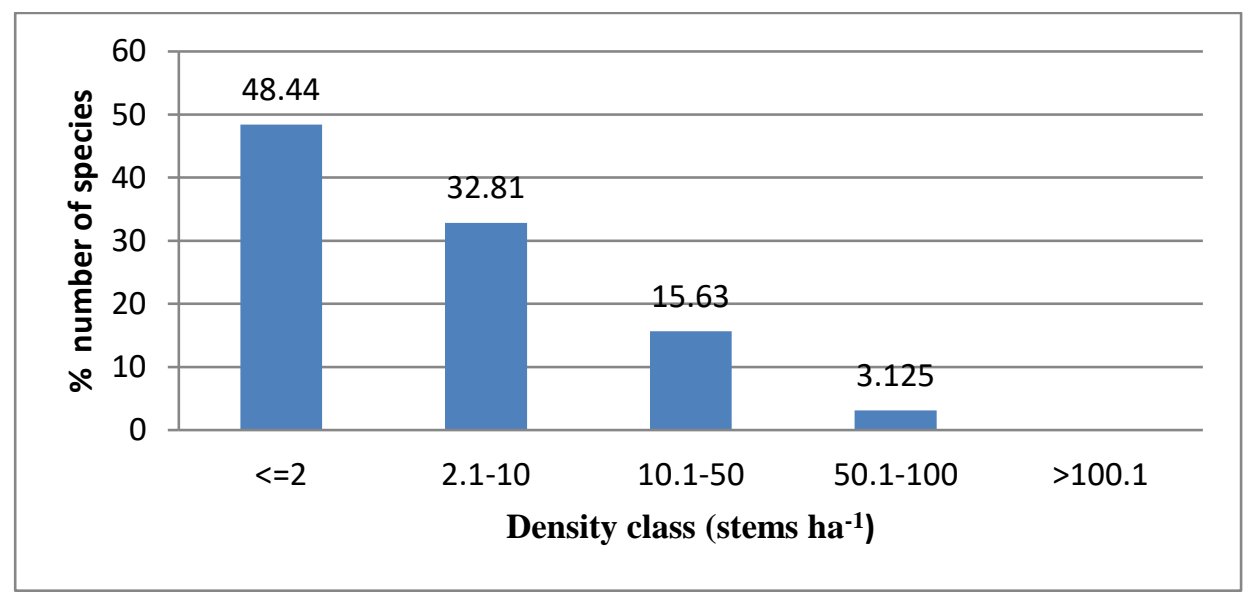

Figure 3: Density of all woody plant species by size class in KSNP 
The most frequent woody species in the study area were Acacia mellifera $(71.4 \%)$, followed by Combretum hartmannianum (59\%), Terminalia brownii (57.8\%), Balanites aegyptiaca (46.0\%), Acacia senegal (42.2\%) and Acacia oerfota (35.4\%), Boswellia papyrifera (29.8\%), Dicrostachy scinerea (29.2). While Acacia albida, Parkinsonia aculeate and Otostegia ellenbeckii each having frequency $(0.62 \%)$ was rarely observed. The relative frequency of species was between 0.09 and $10.6 \%$ with similar orders as their frequencies (Table 1). KSNP were arranged in six frequency classes: $(1=65.1-80,2=50.1-65,3=35.1-50,4=20.1-35 \%, 5=5.1-20$, and $6=\leq 5 \%)$. The woody plant species dominantly concentrated in frequency class $6(<5 \%)$. In $1(65.1-80 \%)$ frequency class the number of species was one (Figure 4).

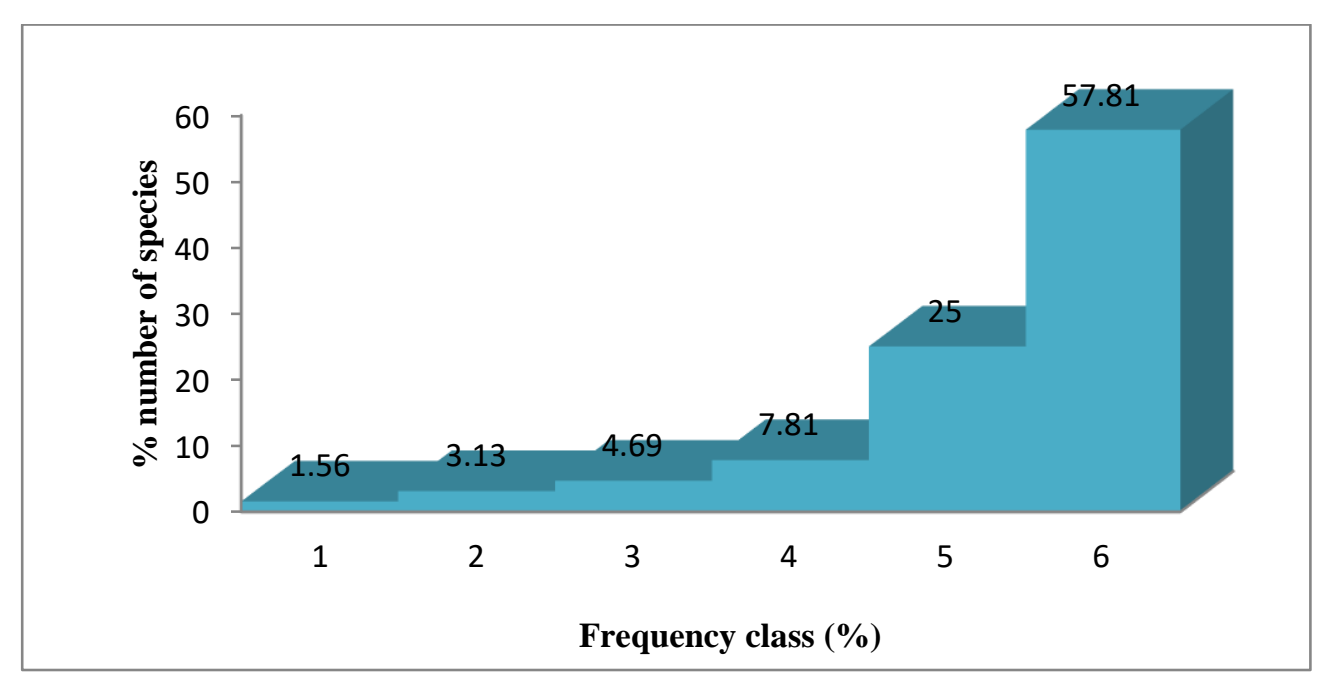

Figure 4: Woody plant species frequency classes' distribution of KSNP $(1=65.1-80,2=50.1-65$, $3=35.1-50,4=20.1-35 \%, 5=5.1-20$, and $6=\leq 5 \%)$.

\subsection{Basal area (BA)}

The total basal area of KSNP of woody species with DBH $\geq 2.5 \mathrm{~cm}$ was $79.3 \mathrm{~m}^{2} \mathrm{ha}^{-1}$. Interms of species Adansonia digitata contributed the highest basal area $\left(35.5 \mathrm{~m}^{2} \mathrm{ha}^{-1}\right)$ followed by Sterculia Africana $\left(7.86 \mathrm{~m}^{2} \mathrm{ha}^{-1}\right)$, Tamarindus indica $\left(5.52 \mathrm{~m}^{2} \mathrm{ha}^{-1}\right)$, Anogeissus leiocarpus $\left(4.09 \mathrm{~m}^{2} \mathrm{ha}^{-1}\right)$, Ficus sycomorus $\left(3.63 \mathrm{~m}^{2} \mathrm{ha}^{-1}\right)$, Acacia lahai $\left(3.57 \mathrm{~m}^{2} \mathrm{ha}^{-1}\right)$, Balanites aegyptiaca $\left(2.90 \mathrm{~m}^{2} \mathrm{ha}^{-}\right.$ $\left.{ }^{1}\right)$,Ziziphus spina-christi $\left(2.87 \mathrm{~m}^{2} \mathrm{ha}^{-1}\right)$ (Table 1).The lowest value was recorded in shrub species of Senna sinqueana $\left(0.002 \mathrm{~m}^{2} \mathrm{ha}^{-1}\right)$, Buddleja polystachya $\left(0.003 \mathrm{~m}^{2} \mathrm{ha}^{-1}\right)$.

\subsection{Importance value index (IVI)}

The importance value index of woody species in KSNP ranged from 0.13 to 30.8. The highest IVI was documented for Adansonia digitata (30.8). Balanites aegyptiaca, Acacia mellifera, Terminalia brownii and Combretum hartmannianum, Anogeissus leiocarpus, Tamarindus indica, 
Ziziphus spina-christi, Sterculia Africana, Acacia Senegal, Boswellia papyrifera and Acacia oerfota had IVI value above ten were the most important species (Table 1).

Table 1: Woody species structure and importance value in Kafta-Sheraro National Park: $\left(\mathrm{AD}=\right.$ Average diameter $(\mathrm{cm}), \mathrm{AB}=$ Abundance (individual stems), $\mathrm{D}=$ Density (Abundance ha ${ }^{-1}$ ), $\mathrm{RD}=$ Relative density (\%), $\mathrm{F}=$ Frequency $(\%), \mathrm{RF}=$ Relative frequency $(\%), \mathrm{BA}=\mathrm{Basal}$ Area $\left(\mathrm{m}^{2} \mathrm{ha}^{-}\right.$ $\left.{ }^{1}\right), \mathrm{DO}=$ Dominance, RDO=Relative dominance $(\%), \mathrm{IVI}=$ Importance value index $\left.(\%)\right)$

\begin{tabular}{|c|c|c|c|c|c|c|c|c|c|c|}
\hline Species & AD & $\mathbf{A B}$ & D & RD & $\mathbf{F}$ & RF & BA & DO & RDO & IVI \\
\hline Acacia senegal & 4.6 & 159 & 24.8 & 5.33 & 42.2 & 6.26 & 0.05 & 0.301 & 0.222 & 11.8 \\
\hline Combretum hartmannianum & 9.4 & 342 & 53.4 & 11.5 & 59 & 8.74 & 0.19 & 2.584 & 1.911 & 22.1 \\
\hline Dalbergia melanoxylon & 8.4 & 46 & 7.19 & 1.54 & 17.4 & 2.58 & 0.14 & 0.262 & 0.194 & 4.31 \\
\hline Balanites aegyptiaca & 38 & 188 & 29.4 & 6.3 & 46 & 6.81 & 2.9 & 19.59 & 14.49 & 27.6 \\
\hline Acacia oerfota & 4.1 & 169 & 26.4 & 5.67 & 35.4 & 5.24 & 0.03 & 0.222 & 0.164 & 11.1 \\
\hline Dicrostachy scinerea & 3.9 & 143 & 22.3 & 4.79 & 29.2 & 4.32 & 0.03 & 0.17 & 0.126 & 9.24 \\
\hline Grewia bicolor & 2.5 & 31 & 4.84 & 1.04 & 9.94 & 1.47 & 0.01 & 0.016 & 0.012 & 2.52 \\
\hline Anogeissus leiocarpus & 45 & 71 & 11.1 & 2.38 & 24.8 & 3.68 & 4.09 & 11.62 & 8.591 & 14.7 \\
\hline Sterculia africana & 62 & 42 & 6.56 & 1.41 & 14.9 & 2.21 & 7.86 & 13.2 & 9.763 & 13.4 \\
\hline Acacia seyal & 5.5 & 34 & 5.31 & 1.14 & 9.94 & 1.47 & 0.06 & 0.08 & 0.059 & 2.67 \\
\hline Maytenus senegallensis & 5.6 & 6 & 0.94 & 0.2 & 2.48 & 0.37 & 0.06 & 0.015 & 0.011 & 0.58 \\
\hline Acacia mellifera & 4.2 & 446 & 69.7 & 15 & 71.4 & 10.6 & 0.03 & 0.623 & 0.46 & 26 \\
\hline Adansonia digitata & 134 & 27 & 4.22 & 0.91 & 10.6 & 1.56 & 35.5 & 38.31 & 28.33 & 30.8 \\
\hline Acacia albida & 17 & 2 & 0.31 & 0.07 & 0.62 & 0.09 & 0.56 & 0.045 & 0.033 & 0.19 \\
\hline Jasminum abyssinicum & 5.2 & 8 & 1.25 & 0.27 & 2.48 & 0.37 & 0.05 & 0.017 & 0.012 & 0.65 \\
\hline Ziziphus spina-christi & 38 & 87 & 13.6 & 2.92 & 23 & 3.4 & 2.87 & 9.989 & 7.387 & 13.7 \\
\hline Tamarindus indica & 52 & 59 & 9.22 & 1.98 & 19.9 & 2.94 & 5.52 & 13.03 & 9.634 & 14.6 \\
\hline Casuarina equisetifolia & 5.2 & 69 & 10.8 & 2.31 & 15.5 & 2.3 & 0.05 & 0.149 & 0.11 & 4.72 \\
\hline Capparis decidua & 4.6 & 4 & 0.63 & 0.13 & 1.24 & 0.18 & 0.04 & 0.007 & 0.005 & 0.32 \\
\hline Grewia villosa & 3.6 & 11 & 1.72 & 0.37 & 4.97 & 0.74 & 0.02 & 0.011 & 0.008 & 1.11 \\
\hline Salvadora persica & 2.8 & 5 & 0.78 & 0.17 & 1.86 & 0.28 & 0.01 & 0.003 & 0.002 & 0.45 \\
\hline Ziziphus mauritiana & 9.8 & 4 & 0.63 & 0.13 & 1.24 & 0.18 & 0.19 & 0.03 & 0.022 & 0.34 \\
\hline Feretia apodanthera & 7.5 & 3 & 0.47 & 0.1 & 2.48 & 0.37 & 0.11 & 0.013 & 0.01 & 0.48 \\
\hline Hyphaene thebaica & 17 & 96 & 15 & 3.22 & 21.1 & 3.13 & 0.61 & 2.352 & 1.74 & 8.09 \\
\hline Calotropis procera & 6.9 & 14 & 2.19 & 0.47 & 5.59 & 0.83 & 0.11 & 0.064 & 0.047 & 1.34 \\
\hline Boswellia papyrifera & 11 & 178 & 27.8 & 5.97 & 29.8 & 4.42 & 0.25 & 1.794 & 1.327 & 11.7 \\
\hline Terminalia brownii & 36 & 205 & 32 & 6.87 & 57.8 & 8.56 & 2.06 & 13.28 & 9.82 & 25.2 \\
\hline Grewia flavescens & 5.5 & 13 & 2.03 & 0.44 & 6.21 & 0.92 & 0.06 & 0.033 & 0.025 & 1.38 \\
\hline Moringa stenopetala & 5.8 & 4 & 0.63 & 0.13 & 1.24 & 0.18 & 0.11 & 0.018 & 0.013 & 0.33 \\
\hline Acacia lahai & 42 & 6 & 0.94 & 0.2 & 2.48 & 0.37 & 3.57 & 0.857 & 0.634 & 1.2 \\
\hline Diospyros mespiliformis & 13 & 30 & 4.69 & 1.01 & 9.32 & 1.38 & 0.35 & 0.42 & 0.311 & 2.7 \\
\hline Burkea africana & 37 & 21 & 3.28 & 0.7 & 7.45 & 1.1 & 2.67 & 2.243 & 1.659 & 3.47 \\
\hline Ficus sycomorus & 43 & 2 & 0.31 & 0.07 & 1.24 & 0.18 & 3.63 & 0.291 & 0.215 & 0.47 \\
\hline Combretum glutinos & 8 & 27 & 4.22 & 0.91 & 5.59 & 0.83 & 0.13 & 0.136 & 0.1 & 1.83 \\
\hline Combretum molle & 6 & 117 & 18.3 & 3.92 & 11.2 & 1.66 & 0.07 & 0.335 & 0.247 & 5.83 \\
\hline Nerium oleander & 2.5 & 3 & 0.47 & 0.1 & 1.24 & 0.18 & 0.01 & 0.002 & 0.001 & 0.29 \\
\hline Cadaba farinosa & 5.4 & 6 & 0.94 & 0.2 & 1.24 & 0.18 & 0.06 & 0.014 & 0.01 & 0.4 \\
\hline Leptadenia lanceolata & 4.6 & 3 & 0.47 & 0.1 & 1.86 & 0.28 & 0.03 & 0.004 & 0.003 & 0.38 \\
\hline Terminalia laxiflora & 8.7 & 10 & 1.56 & 0.34 & 1.24 & 0.18 & 1.05 & 0.419 & 0.31 & 0.83 \\
\hline Solanum incanum & 2.6 & 7 & 1.09 & 0.23 & 1.86 & 0.28 & 0.01 & 0.004 & 0.003 & 0.51 \\
\hline
\end{tabular}




\begin{tabular}{lrrrrrrrrrr}
\hline \multicolumn{1}{c}{ Species } & AD & AB & D & RD & F & RF & BA & DO & RDO & IVI \\
\hline Grewia mollis & 4.8 & 4 & 0.63 & 0.13 & 1.86 & 0.28 & 0.04 & 0.007 & 0.005 & 0.42 \\
Lannea microcarpa & 11 & 23 & 3.59 & 0.77 & 8.7 & 1.29 & 0.25 & 0.232 & 0.172 & 2.23 \\
Commiphora boranensis & 7.2 & 32 & 5 & 1.07 & 4.35 & 0.64 & 0.72 & 0.922 & 0.682 & 2.4 \\
Stereospermum kunthianum & 6.9 & 21 & 3.28 & 0.7 & 6.21 & 0.92 & 0.1 & 0.08 & 0.059 & 1.68 \\
Pittosporum viridiflorum & 9 & 17 & 2.66 & 0.57 & 3.73 & 0.55 & 0.42 & 0.047 & 0.034 & 1.16 \\
Boscia angustifolia & 6.4 & 7 & 1.09 & 0.23 & 1.86 & 0.28 & 0.08 & 0.022 & 0.016 & 0.53 \\
Acacia sp. & 11 & 11 & 1.72 & 0.37 & 2.48 & 0.37 & 0.25 & 0.109 & 0.08 & 0.82 \\
Ziziphus mucronata & 2.9 & 17 & 2.66 & 0.57 & 6.21 & 0.92 & 0.02 & 0.011 & 0.008 & 1.5 \\
Acacia polyacantha & 5.9 & 46 & 7.19 & 1.54 & 4.35 & 0.64 & 0.07 & 0.126 & 0.093 & 2.28 \\
Acacia etbaica & 11 & 5 & 0.78 & 0.17 & 1.24 & 0.18 & 0.22 & 0.045 & 0.033 & 0.38 \\
Acacia tortilis & 12 & 8 & 1.25 & 0.27 & 1.86 & 0.28 & 0.27 & 0.088 & 0.065 & 0.61 \\
Parkinsonia aculeata & 8.4 & 1 & 0.16 & 0.03 & 0.62 & 0.09 & 0.14 & 0.006 & 0.004 & 0.13 \\
Ricinus communis & 4.1 & 4 & 0.63 & 0.13 & 0.62 & 0.09 & 0.03 & 0.005 & 0.004 & 0.23 \\
Melia azedarach & 4.6 & 3 & 0.47 & 0.1 & 1.24 & 0.18 & 0.04 & 0.005 & 0.004 & 0.29 \\
Carissa edulis & 5.4 & 11 & 1.72 & 0.37 & 1.86 & 0.28 & 0.07 & 0.033 & 0.024 & 0.67 \\
Combretum sp. & 8.9 & 27 & 4.22 & 0.91 & 2.48 & 0.37 & 0.16 & 0.174 & 0.129 & 1.4 \\
Sclerocarya birrea & 19 & 15 & 2.34 & 0.5 & 3.11 & 0.46 & 0.7 & 0.419 & 0.31 & 1.27 \\
Terminalia sp. & 7.6 & 7 & 1.09 & 0.23 & 1.24 & 0.18 & 0.11 & 0.032 & 0.024 & 0.44 \\
Diospyros abyssinica & 8 & 14 & 2.19 & 0.47 & 2.48 & 0.37 & 0.30 & 0.226 & 0.167 & 1 \\
Brucea antidysentrica & 15 & 3 & 0.47 & 0.1 & 1.24 & 0.18 & 0.12 & 0.053 & 0.039 & 0.32 \\
Plumbago zeylanica & 2.5 & 5 & 0.78 & 0.17 & 1.86 & 0.28 & 0.01 & 0.002 & 0.002 & 0.45 \\
Otostegia ellenbeckii & 2.5 & 2 & 0.31 & 0.07 & 0.62 & 0.09 & 0.004 & 0.008 & 0.006 & 0.16 \\
Senna sinqueana & 2.5 & 1 & 0.16 & 0.03 & 0.62 & 0.09 & 0.002 & 0.007 & 0.005 & 0.13 \\
Buddleja polystachya & 2.6 & 2 & 0.31 & 0.07 & 1.24 & 0.18 & 0.003 & 0.011 & 0.008 & 0.26 \\
\hline & - & $\mathbf{2 9 8 4}$ & $\mathbf{4 6 6}$ & $\mathbf{1 0 0}$ & - & $\mathbf{1 0 0}$ & $\mathbf{7 9 . 3}$ & - & $\mathbf{1 0 0}$ & $\mathbf{3 0 0}$ \\
\hline
\end{tabular}

\subsection{Population structure of KSNP forest and selected tree species}

The general DBH and height class distribution of woody species density in the KSNP showed an Inverted-J shaped structure. The distribution of trees and shrubs was categorized into nine DBH class: $(2.5-10 \mathrm{~cm} ; 10.1-20 \mathrm{~cm} ; 20.1-30 \mathrm{~cm} ; 30.1-40 \mathrm{~cm} ; 40.1-50 \mathrm{~cm}, 50.1-60 \mathrm{~cm} ; 60.1-70 \mathrm{~cm} ; 70.1-$ $80 \mathrm{~cm}$ and $>80.1 \mathrm{~cm}$ ). The majority of individuals are distributed in the first DBH class $2.5-10 \mathrm{~cm}$ (Figure 5a). Three species of twenty individuals of Anogeissus leiocarpus, Sterculia Africana, Adansonia digitata had a DBH of $70 \mathrm{~cm}$ and above.

In KSNP the highest DBH was recorded for fourteen individuals of Adansonia digitata (110$146 \mathrm{~cm})$. While Tree height distribution was classified in seven classes: $<=4 \mathrm{~m} ; 4.1-9 \mathrm{~m} ; 9.1-14 \mathrm{~m}$; 14.1-19m; 19.1-24m; 24.1-29m and $>29.1 \mathrm{~m}$. There is higher number of trees/shrubs individuals in the height class below $14 \mathrm{~m}$ which accounts $81 \%$ of the total population height classes. Anogeissus leiocarpus, Adansonia digitata, Tamarindus indica, Sterculia Africana, Diospyros 
mespiliformis and Balanites aegyptiaca had 39 individuals having above $15 \mathrm{~m}$ height. The highest height was recorded for Anogeissus leiocarpus (30m) (Figure 5b).

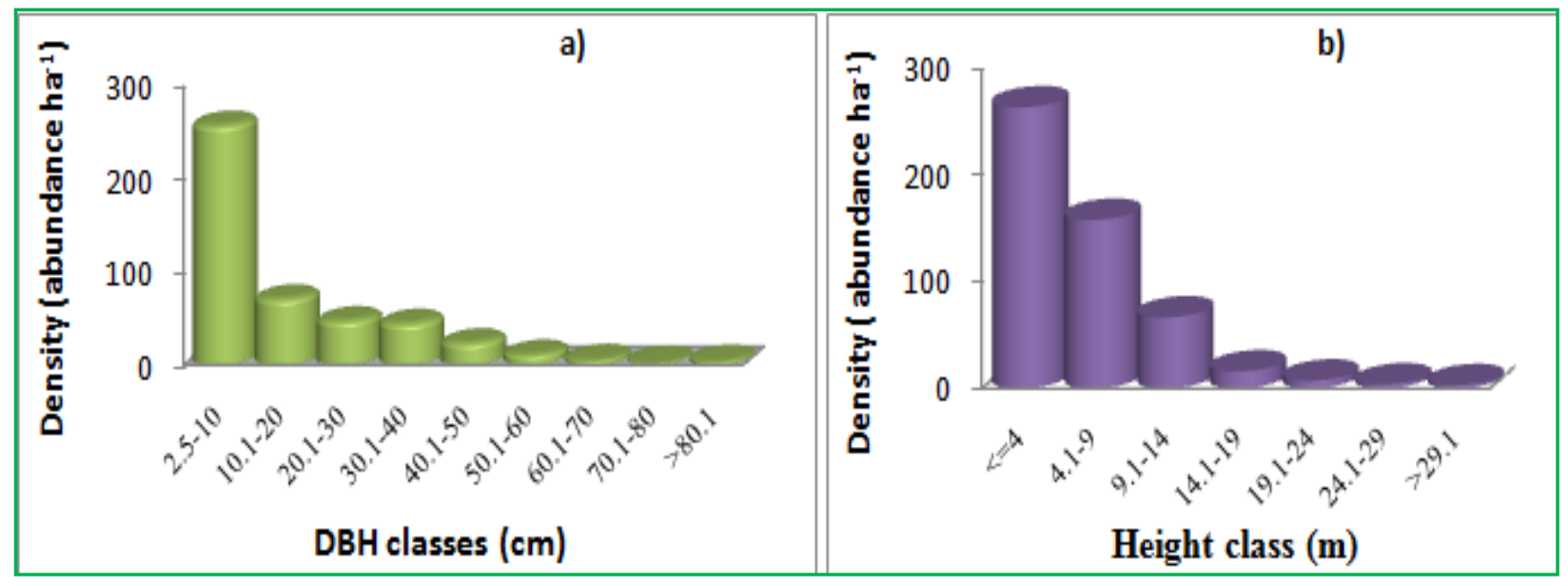

Figure 5: Woody species diameter (a) and height (b) classes of Kafta-sheraro National Park

The analysis of population structure of Kafta-sheraro national park individual tree species in nine DBH classes dominantly showed eight patterns of population structure. First pattern consists of individual species concentrated only in the first DBH class $(2.5-10 \mathrm{~cm})$ but absent in the rest classes and represented by Acacia mellifera (F.g.6a). Species in this group are Acacia senegal, Dalbergia melanoxylon, Acacia oerfota, Dicrostachy scinerea and Acacia seyal. Second pattern occupied both first $(2.5-10 \mathrm{~cm})$ and second $(10.1-20 \mathrm{~cm}) \mathrm{DBH}$ classes and represented by Combretum hartmannianum and Boswellia papyrifera (F.g.6b). Third pattern was an Inverted-J shaped in which the highest number of individuals was present in lower DBH classes and species Anogeissus leiocarpus only (F.g.6c). Fourth pattern was J-shaped in which a higher proportion of individuals were present at higher DBH classes and the trend decreased towards lower DBH classes. Species of this pattern was Ziziphus spina-christi and Tamarindus indica (F.g.6d). Fifth pattern was bell shaped in which a higher proportion of species were present in intermediate DBH classes and the trend decreased in lower and higher DBH classes. Species in this category were Balanites aegyptiaca and Terminalia brownii (F.g.6e). Sixth pattern occurred in the second DBH class $(10.1-20 \mathrm{~cm})$ and the only representative species is Diospyros mespiliformis (F.g.6f). Seventh pattern shows irregular distribution over diameter classes. Some DBH classes had small number of individuals while other DBH classes had large number of individuals and even some were missed. The known species is Sterculia Africana (F.g.6g). Eighth pattern the DBH occurred only 
in the large class. Adansonia digitata was the only representative species that occur in the ninth (>80.1cm) DBH class (F.g.6h).
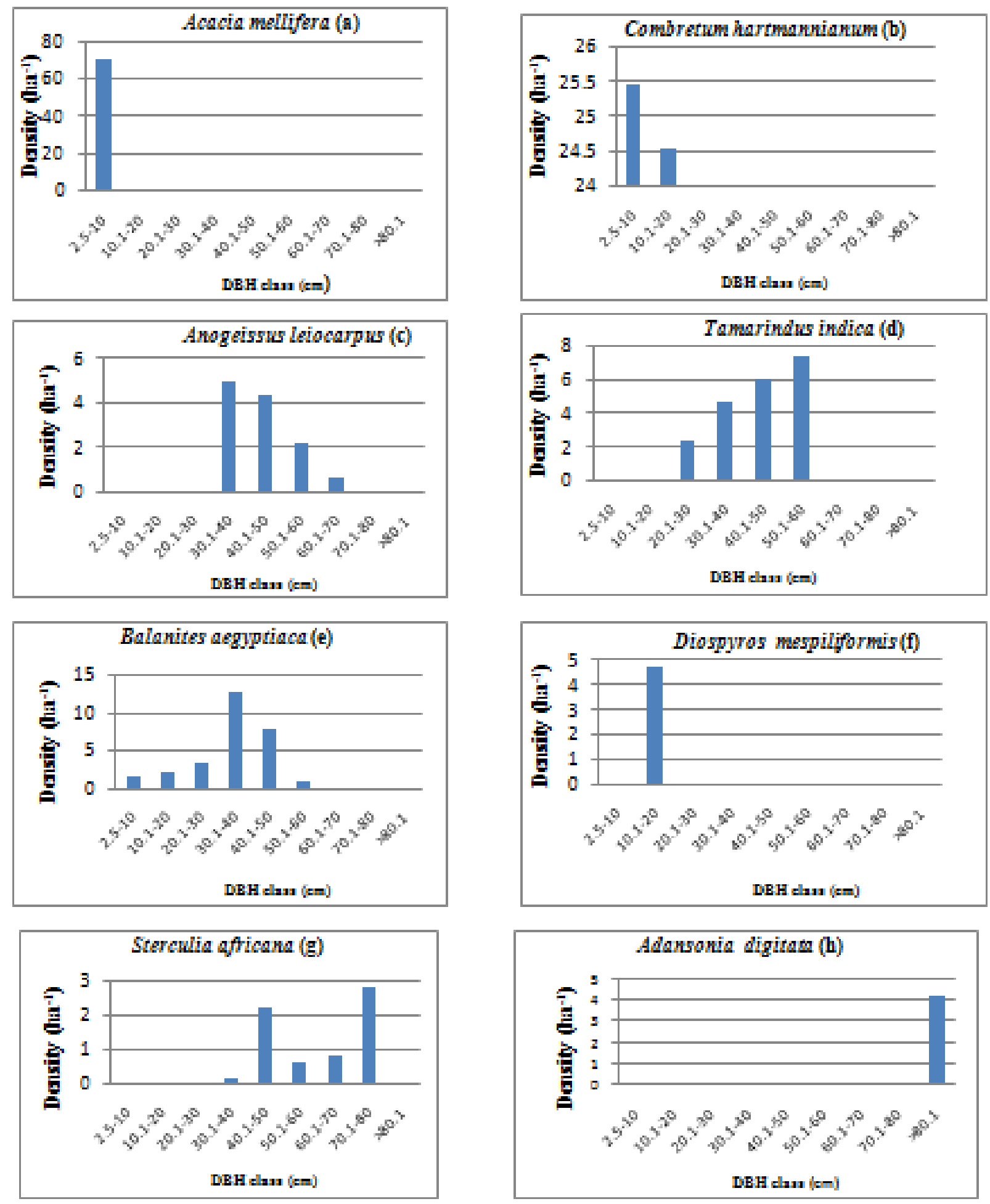

Figure 6: Representative population structure patterns of each tree species in KSNP 


\subsection{Regeneration status of KSNP woody species}

A total of 378 individuals of seedling 68 (2.023\%) and saplings 310 (9.22\%) belonging to 64 woody species were counted from all quadrats. Twelve woody species had sapling and seedling, five species had only sapling while 47 species lack both stages. Woody species having seedling were Acacia senegal, Combretum hartmannianum, Balanites aegyptiaca, Acacia oerfota, Dicrostachy scinerea, Acacia mellifera, Ziziphus spina-christi, Casuarina equisetifolia, Hyphaene thebaica, Boswellia papyrifera, Terminalia brownii and Acacia polyacantha (Appendix 1). The total density of seedling and sapling had 10.7 and 48.6 individuals' ha ${ }^{-1}$ respectively (Figure 7a). Relatively higher sapling density was exhibited by species like Hyphaene thebaica (16.1\%) followed Balanites aegyptiaca (15.8\%), Dicrostachy scinerea (13.17\%), Casuarina equisetifolia (8.64\%), and Acacia Senegal (7.82\%) (Appendix 1).

In Kafta-sheraro national park forest $18.75 \%$ of tree/ shrub species showed 'fair regenerating' while $7.8 \%$ and $73.45 \%$ showed 'poor regenerating' and 'none regenerating' condition respectively. But "good" and "new" regenerating status of the tree species was absent (Figure 7b). Dalbergia melanoxylon, Acacia seyal, Grewia villosa, Combretum molle and Plumbago zeylanica had 'poor' regenerating woody species.

a)

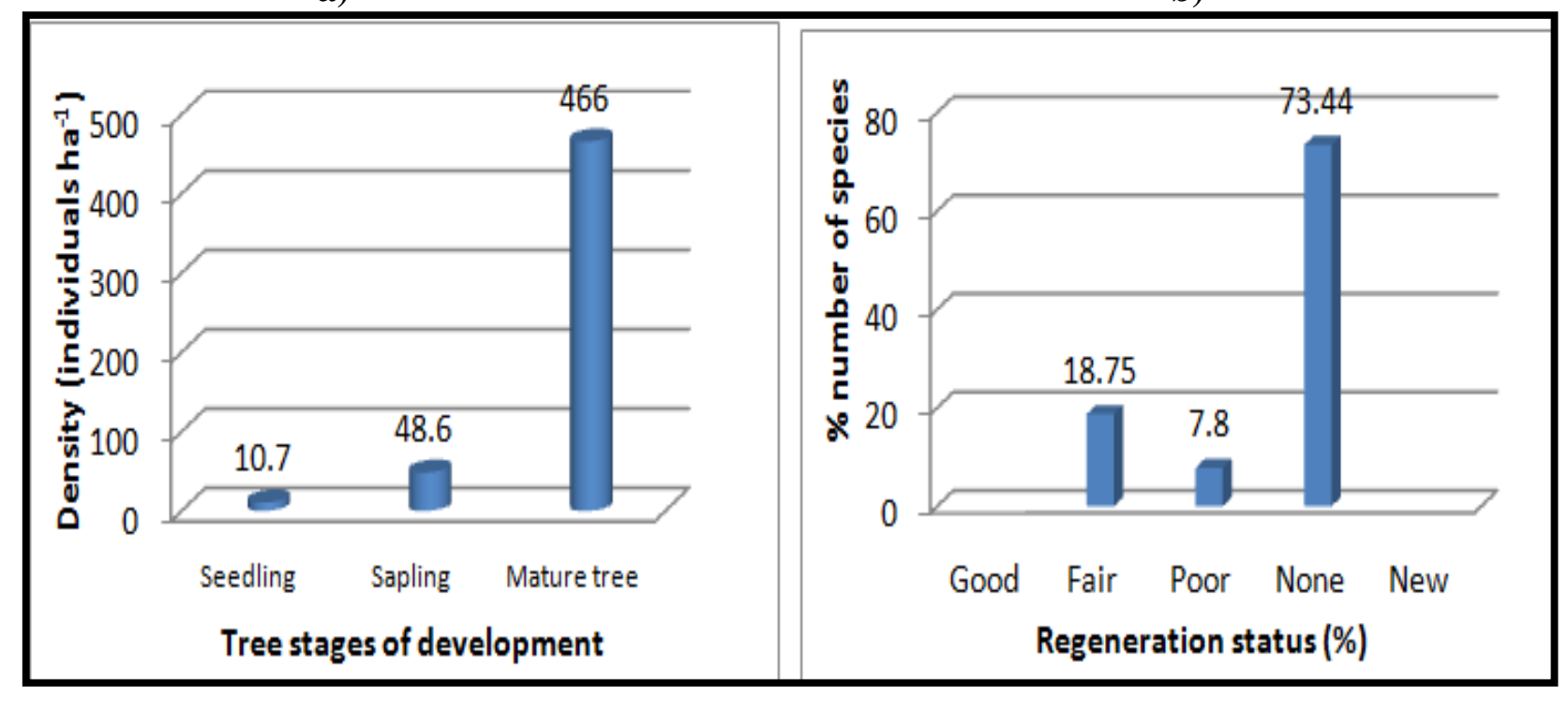

Figure 7: Density of seedling, sapling \& mature tree species (a) and regeneration status of woody plants in KSNP forest (b) 


\section{Discussion}

\subsection{Woody species structure}

Density: Species-abundance measures are ways of expressing not only the relative richness but also evenness and assessing diversity (Barnes et al., 1998). The total density of woody species of the study was $466 \pm 12.8$ individuals ha $^{-1}$ (64 species) which is lower than Babile elephant sanctuary:1319 individuals' ha ${ }^{-1}$ (67 species) (Anteneh et al., 2011); Nechisar Park: 887 stems ha $^{-}$ ${ }^{1}$ (118 species) (Samson et al., 2010); Yemrehane Kirstos Church forest (506.6 stems ha-1, Amanuel and Gemedo, 2018); Zege Peninsula (3318 stems ha ${ }^{-1},(113$ species) Alemnew et al., 2007); (1845 stems ha-1, Abyot et al. 2014); Tara Gedam and Abebaye (3001 stems ha ${ }^{-1}$ and 2850 stems ha ${ }^{-1}$ (143 species) Haileab et al., 2011); Kahtasa forest (505 stems ha ${ }^{-1}$, Getaneh et al., 2019) ; Wof-Washa forest (698.8 stems ha ${ }^{-1}$ ) (Gebremicael et al., 2013) in Ethiopia and in other tropical forests (515 stems ha ${ }^{-1}$ ) (Chauhan et al., 2008a).The densities of tree species variation in forests was reported due to variation in species composition, age structure (Ademoh et al., 2017) and the degree of disturbance (Sharma and Chaudhry, 2018).

Acacia mellifera, Combretum hartmannianum, Terminalia brownii, Combretum molle, Balanites aegyptiaca, Acacia oerfota, Boswellia papyrifera, Acacia Senegal, Dicrostachy scinerea occupied above $50 \%$ of the total stem density and relatively those species had higher seedling and sapling density in the study area. These species are probably due to their resistance to drought and disturbance (Abiyot et al., 2017). The absence of seedlings in some of the canopy trees of Sterculia africana and Adansonia digitata highly attributed to disturbance, seed predation, and habitat unsuitability. Disturbance and seed predation have been played sound role in reducing the seedling population of woody species (Alemayehu et al., 2009).

Frequency: contributes to indicate homogeneity and heterogeneity of vegetation of a given species (Haileab et al., 2005). The study site has high species heterogeneity; because of higher percentage numbers of species were found in the lower frequency class than higher class.

According to lamprecht (1989) low value in lower frequency and high value in higher frequency class indicate similar species composition. To the reverse low percentage number of species in the higher frequency and low percentage number of species in the higher frequency classes reported a high degree of floristic heterogeneity (Simon and Girma, 2004; Abyot et al., 2014; Amanuel and Gemedo, 2018). The variation in density and frequency between species may be attributed to 
habitat differences, habitat preferences among the species, species characteristics for adaptation, degree of exploitation and conditions for regeneration (Haileab et al., 2011). In KSNP important portions of the species were rare. Therefore, the study site has existence of high floristic heterogeneity.

Basal area: The basal area of all Kafta-sheraro national park woody vegetation $\left(79.3 \mathrm{~m}^{2} \mathrm{ha}^{-1}\right)$ is much higher than dry land areas of Ethiopia forests and other countries. NNP $\left(49.45 \mathrm{~m}^{2} \mathrm{ha}^{-1}\right.$, Samson et al., 2010); Babile elephant sanctuary (17.8 $\mathrm{m}^{2} \mathrm{ha}^{-1}$; Anteneh et al., 2011);(19.3 $\mathrm{m}^{2} \mathrm{ha}^{-1}$, Abyot et al., 2014); Grat-Kahsu (8.25 $\mathrm{m}^{2} \mathrm{ha}^{-1}$, Tesfay et al., 2019); Abebaye forest (49.45 $\mathrm{m}^{2} \mathrm{ha}^{-1}$, Haileab et al., 2011) (72 $\mathrm{m}^{2} \mathrm{ha}^{-1}$, Amanuel and Gemedo, 2018); virgin tropical forests in Africa (23-37 $\mathrm{m}^{2} \mathrm{ha}^{-1}$, Lamprecht, 1989); Katerniaghat Wildlife Sanctuary (35.9 $\mathrm{m}^{2} \mathrm{ha}^{-1}$, Tripathi \& Singh., 2009); Gibbon Wildlife Sanctuary (9.62 $\mathrm{m}^{2} \mathrm{ha}^{-1}$ : Sarkar and Devi, 2014); Chilimo Forest (30 $\mathrm{m}^{2} \mathrm{ha}^{-1}$,Tamrat, 1993), Adelle Forest :26 $\mathrm{m}^{2} \mathrm{ha}^{-1}$ and Boditi Forest:23 $\mathrm{m}^{2} \mathrm{ha}^{-1}$ ) (Haile et al., 2008); Jibat (59.79 $\mathrm{m}^{2} \mathrm{ha}^{-1}$,Tesfaye et al., 2013); Komto forest (Fekadu et al., 2012); Bhadra Wildlife Sanctuary(18.09 $\mathrm{m}^{2} \mathrm{ha}^{-1}$, Krishnamurthy et al., 2010); Metema (42.54, $\mathrm{m}^{2} \mathrm{ha}^{-1}$,Haile et al., 2012a). But it was less than moist forests; Wof-Washa Forest (102 $\mathrm{m}^{2} \mathrm{ha}^{-1}$,Tamrat, 1993); Berbere forest (87.49 $\mathrm{m}^{2} \mathrm{ha}^{-1}$,Tesfaye et al., 2017b); Belete forest (103.5 $\mathrm{m}^{2} \mathrm{ha}^{-1}$, Kflay \& Kitessa, 2014); Tara Gedam ( $115.36 \mathrm{~m}^{2} \mathrm{ha}^{-1}$, Haileab et al., 2011) and Kimphe lafa forest $\left(114.4 \mathrm{~m}^{2} \mathrm{ha}^{-1}\right.$ ,Kedir et al., 2015).

The highest basal area from individual tree species in the study was contributed by Adansonia digitata $\left(35.5 \mathrm{~m}^{2} \mathrm{ha}^{-1}\right)$ while the highest density was Acacia mellifera species (69.7 individuals ha ${ }^{-}$ ${ }^{1}$ ). This indicates that species with the highest basal area do not necessarily have the highest density and the vi-versa is also true. This was indicated that size difference between species is common in natural vegetation (Tamrat, 1994; Simon and Girma, 2004).

Importance Value Index: is useful to compare the ecological significance of species (Lamprecht, 1989; Premavani et al., 2014). Important value index is the degree of dominancy and abundance of a given species in relation to the other species in the area (Kent \& Coker, 1992). The importance value index (IVI) of woody species in the study area was generally comparable to other areas of woody vegetation (Haileab et al., 2011; Desalegn et al., 2013; Abiyot et al., 2017). For example, in Jibat forest Ilex mitis species had the highest value (27.7\%) (Tesfaye et al., 2013); 34.6\% (Kflay and Kitessa, 2014). 30\% woody species had IVI value of one and lower which categorized rarest 
list. Some of the least IVI record was Maytenus senegallensis, Acacia albida, Jasminum abyssinicum, Salvadora persica, Ziziphus mauritiana, Feretia apodanthera. Moreover, least important species are usually found in open woodlands and savanna (Hedberg \& Hedberg, 2003). The IVI values can also be used to prioritize species for conservation, and species with high IVI value need less conservation efforts, whereas, those having low IVI value need high conservation effort. Lower IVI may indicate woody species are threatened and need immediate conservation measure (Anteneh et al., 2011; Temesgen et al., 2015). Low IVI value and poor regeneration status of species in a forest need to be prioritized for conservation (Haileab et al., 2011).

Population structure: DBH and height are important indicators of forest reproduction and health status (Schulz et al., 2009). The general pattern DBH of KSNP showed an inverted J-shaped distribution where species frequently had the highest frequency in low diameter classes and a gradual decrease towards the higher class. Inverted J shape pattern is normal population structure and shows the existence of species in healthier condition. Similar results were reported by (Abate et al. 2006; Haile et al., 2008; Ermias et al., 2008; Leul et al., 2010; Samson et al., 2010; Tesfaye et al., 2013; Kflay and Kitessa, 2014; Mligo., 2015; Tesfaye et al., 2017b; and Tesfay et al., 2019). However, the general pattern does not clearly show trends of population dynamics and recruitment processes of a single species (Abyot et al., 2014; Getaneh et al., 2019). Other seven discontinuous (there were complete absences of individuals in some class and fairly representative of the individual in other class) patterns showed in KSNP. Irregular distribution pattern were reported by (Mekuria et al., 1999, Getachew et al., 2002, Haile et al., 2008, Ensermu \& Teshome, 2008; Haile et al., 2012a; Melkamu and Abdella, 2019). Moreover, assessing the population structure has been helped to provide initial idea about the status of regeneration pattern of woody plants (Swamy et al., 2000).

\subsection{Regeneration status of woody plants}

Reports stated that the regeneration status of the given natural vegetation is considered as none regenerating if a species is absent both in sapling and seedling stages but present as mature (Khumbongmayum et al., 2006; Dhaulkhandi et al., 2008; Tiwari et al., 2010). Therefore, the regeneration status of Kafta-sheraro national park was considered as none regenerating since mature $(88.76 \%)>$ sapling $(9.22 \%)>$ seedling $(2.02 \%)$. The regeneration and recruitment condition of woody species is one of the major factors that are useful to assess their conservation status (Bekele et al., 2002). The population structure, characterized by the presence of sufficient 
population of seedlings, saplings and adults, indicates successful regeneration of forest species (Saxena and Singh, 1984). However, climatic factors and biotic interference influence the regeneration of species in any vegetation (Henle et al., 2004; Dhaulkhandi et al., 2008). The tree species, which had no seedlings and saplings exhibited discontinuous population structures (Getaneh et al., 2019).

The "poor" and "none" regenerating categories which constitute around $81.25 \%$ of the woody plant in KSNP have many important and useful tree species. For example trees/ shrub species namely: Sterculia africana, Acacia seyal, Adansonia digitata, Hyphaene thebaica, Burkea Africana and Grewia flavescens are source of feed for African elephant some plants in the study like Boswellia papyrifera, have economic value. Poor and none regenerating category of woody species was reported in Berbere forest (32.26\%, Tesfaye et al., 2017b); Grat-Kahsu (26.56\%, Tesfay et al., 2019); Gibbon Wildlife Sanctuary (25\%, Sarkar \& Devi, 2014);Wof-Washa (48\%, Gebremicael et al., 2013).

The regeneration status of the tree species of KSNP dominantly falls in "poor" and "not regenerating" status. Such situation might have been occurred through the existing disturbance like, over grazing (Emiru et al., 2007; Kuijper et al., 2010; Norden et al., 2011), firewood collection, fire, mining and poor biotic potential of tree species which either affect the fruiting or seed germination or successful conversion of seedling to sapling stage and similarly reported in Ethiopia (Haileab et al., 2011; Gebremicael et al., 2013; Tesfaye et al., 2017b; Getaneh et al., 2019; Melkamu and Abdella, 2019) and in other tropical dry forests (Ceccon et al., 2006; Anitha et al., 2010). Moreover, individuals in young stages of any species are more vulnerable to any kind of environmental stress and anthropogenic disturbance (Nagamatsu et al., 2002; Getachew et al., 2002). Poor regenerating leads poor reproduction and hampered regeneration either due to the fact that most trees are not producing seeds as a result of their old age or there has been loss of seeds by predators after reproduction (Bhuyan et al., 2003; Khumbongmayum et al., 2006; Mwavu and Witkowski, 2009). Absence of seedlings and saplings of tree species indicates urgent need for targeted forest management plan to enhance regeneration (Abyot et al., 2014; Getaneh et al., 2019). High herbaceous cover played a major role in preventing successful seed germination, seedling establishment, growth and survival (Kobe and Vriesendorp, 2011).

\section{Conclusion and recommendation}


Surveying on structure, and regeneration status of tree species would be provided baseline information and an instrument for the development of successful conservation strategies in KSNP forest. Population structure of most common species of trees and shrubs revealed different patterns of population structure, addressing a high variation among species population dynamics within the forest and an indication for low regeneration. The additional patterns were indicated the absence of populations in various DBH classes. This clearly shows tree species in different stage of development are abnormal population structure status. The regeneration status of the tree species of the study site dominantly showed "poor" and "none" regeneration status but $18 \%$ trees/shrubs species, falls under "fair" regenerating" status. Variation in population structure and regeneration status indicates that long time past disturbance of species and the whole resources of the park. The IVI values reveal the most ecologically important woody species in the forests are in poor regeneration status due to human disturbance, particularly livestock grazing, fire and cultivation. Therefore, the regeneration status of the woody plant species in the park generally categorized under poor and none regenerating condition; research development is needed on soil seed bank and propagation method of each tree species to stimulate regeneration specifically on species of Sterculia Africana, Adansonia digitata, Tamarindus indica, Acacia seyal and Burkea Africana. The park as the habitat for different types of wildlife particularly for the population of African elephant; government and community must give conservation and management priority for species with IVI less than $1 \%$, species with no seedling, and families represented by only one species. Design conservation strategies for those economically important tree species like Boswellia papyrifera which are needed for their effective productivity and this contributes to the conservation and development of other related tree species in the park.

\section{Acknowledgement}

We would like to thank the Ethiopian wildlife conservation authority (Enhanced Management and Effectiveness of Ethiopia's Protected Area Estate Project) which has supported financially starting from vegetation data collection to paper accomplishment. We are also deeply gratitude to Kafta-sheraro national park SCOUTS for their unlimited assistance during four months field work. Without their devoted assistance, the field data collection in such remote and harsh environment would have been impossible.

\section{References}


Abate Ayalew, Tamerat Bekele and Sebsebe Demissew, (2006). The Undifferentiated Afromontane forest of Denkoro in the central highland of Ethiopia: A floristic and Structural Analysis. Ethiopian Journal of Science, 29(1):45-56.

Abiyot Berhanu, Sebsebe Demissew, Zerihun Woldu and Motuma Didita, (2017). Woody species composition and structure of Kuandisha Afromontane forest fragment in northwestern, Ethiopia. Journal of Forestry Research, 28:343-355.

Abiyou Tilahun, Teshome Soromessa, Ensermu Kelbessa and Abyot Dibaba, (2011). Floristic Composition and Community Analysis of Menagesha Amba Mariam Forest (Egdu Forest) in Central Shewa, Ethiopia. Ethiopian Journal of Biological Science, 10:111-136.

Abyot Dibaba, Teshome Soromessa, Ensermu Kelbessa and Abiyou Tilahun, 2014. Diversity, Structure and Regeneration Status of the Woodland and Riverine Vegetation of Sire Beggo in Gololcha District, Eastern Ethiopia. Momona Ethiopian Journal of Science (MEJS), 6(1):70-96.

Ademoh, F. O., J. I. Muoghalu, and B. Onwumere. 2017. "Temporal Pattern of Tree Community Dynamics in a Secondary Forest in Southwestern Nigeria, 29 Years after a Ground Fire." Global Ecology and Conservation, 9:148-170.

Alemayehu Wassie, Sterck, F.J., Demel Teketay and Bongers, F. (2009). Effects of livestock exclusion on tree regeneration in Church forests of Ethiopia. Forest Ecology and Management, 257:765-772.

Alemnew alelign, Demel teketay, Yonas yemshaw \& Sue edwards, 2007. Diversity and status of regeneration of woody plants on the peninsula of Zegie, northwestern Ethiopia. Tropical Ecology, 48(1):37-49.

Amanuel Ayanaw and Gemedo Dalle,(2018). Woody Species Diversity, Structure, and Regeneration Status of Yemrehane Kirstos Church Forest of Lasta Woreda,North Wollo Zone, Amhara Region, Ethiopia. International Journal of Forestry Research, 5302523, 8p.

Anitha, K., Joseph, S. Chandran, R. J. Ramasamy, E. and Prasad, S. N. 2010. "Tree Species Diversity and Community Composition in a Human-dominated Tropical Forest of Western Ghats Biodiversity Hotspot, India." Ecological Complexity, 7:217-224.

Anteneh Belayneh, Tamrat Bekele, Sebsebe Demissew, 2011. The natural vegetation of Babile elephant sanctuary, eastern Ethiopia: implications for biodiversityconservation. Ethiop. J. Biol. Sci. 10 (2), $137 \mathrm{e} 152$.

Barnes, B.V., Zak, D.R., Denton, S.R, and Spurr, S.H. 1998. Forest Ecology, $4^{\text {th }}$ edition. New York: John Wiley and Sons.

Bekele Taye, Getachew Berhan, Elias Taye Matheos, Ersado, Kumlachew, Yeshitela, 2002. Regeneration status of moist montane forests of Yayu Ethiopia: conservation, part I: Boginda, Bonga, Masha Anderacha and forests. Walya, 22:45e60.

Bhuyan P., Khan M.L \& Tripathi R.S. 2003. Tree diversity and population structure in undisturbed and human-impacted stands of tropical wet evergreen forest in Arunachal Pradesh, Eastern Himalayas India. Biodiversity Conservation, 12 (8): 1753-1773.

Brundrett, M., Bougher, N., Dell, B., Grove T. and Malajczuk, N. (1996). Working with Mycorrhizas in forestry and agriculture. AClAR Monograph 32, $374+\mathrm{x}$.

Cain, P.D. 1959. Manual of Vegetation Analysis. Harper and Row, New York, 325p.

Cain, S.A. (1938). The species-area curve. American Midland Naturalist, 19:573-581.

Ceccon, E., Huante, P. and Rincón, E. 2006. Abiotic Factors Influencing Tropical Dry Forests Regeneration. An International journal Brazilian Archives of Biology and Technology, 49 (2):305312.

Chauhan, D., C. Dhanai, B. Singh, S. Chauhan, N. Todaria, and M. Khalid. 2008a. "Regeneration and Tree Diversity in Natural and Planted Forests in a Terai-Bhabhar Forest in Katarniaghat Wildlife Sanctuary, India." Tropical Ecology, 49:53-67.

Chauhan, P., J. Negi, L. Singh, and R. Manhas. 2008b. "Regeneration Status of Sal Forests of Doon Valley."Annals of Forestry, 16:178-182. 
Desalegn Tadele, Ermias Lulekal, Destaw Damtie and Adane Assefa, (2013). Floristic diversity and regeneration status of woody plants in Zengena forest, a remnant montane forest patch in northwestern Ethiopia. Journal of Forestry Research, 25 (2):329-336.

Dhaulkhandi, M., Dobhal, A., Bhatt, S. and Kumar, M. (2008). "Community structure and regeneration potential of natural forest site in Gangotri, India."Journal of Basic \& Applied Sciences, 4:49-52.

Duchok, R. K., Kent, A. D. and Khumbongmayum, A. (2005). Population Structure and Regeneration Status of Medicinal Tree Illicium griffithii in Relation to Disturbance Gradients in Temperate Broad-Leaved Forest of Arunachal Pradesh. Current Science, 89: 673-676.

Edwards, S., Sebsebe Demissew and Hedberg, I. (1997). Flora of Ethiopia and Eritrea (vol. 6): Hydrocharitaceae to Arecaceae. Addis Ababa and Uppsala: The National Herbarium. 586p.

Edwards, S., Sebsebe Demissew, Mesfin Tadesse and Hedberg, I. (1995). Flora of Ethiopia and Eritrea (vol.2:1):Magnoliaceae to Flacourtiaceae. Addis Ababa and Uppsala: The National Herbarium. 532p.

Emiru Birhane, Demel Teketay and Pia Barklund, 2007. Enclosures to Enhance Woody Species Diversity in the Dry Lands of Eastern Tigray, Ethiopia. East African Journal of Sciences, 1(2):136-147.

Ensermu Kelbessa and Sebsebe Demissew (2014). Diversity of vascular plant taxa of the Flora of Ethiopia and Eritrea. Ethiop. J. Biol. Sci.13 (Supp.):37-45.

Ensermu Kelbessa and Teshome Soromessa (2008). Interfaces of regeneration, structure, diversity and uses of some plant species in Bonga forest: a reservoir for wild coffee gene pool. SINET: Ethiop. J. Sci. 31(2):121-134.

Ensermu Kelbessa, Sebsebe Demissew, Zerihun Woldu and Edwards, S. (1992). Some threatened endemic plants of Ethiopia. In: Botany 2000: East and Central Africa (Edwards, S. and Zemede Asfaw, eds). NAPERICA Monograph Series No. 2. Pp. 3555.

Ermias Lulekal, Ensermu Kelbessa, Tamrat Bekele, and Haile Yineger, (2008). Plant Species Composition and Structure of the Mana Angetu Moist Montane Forest, South-Eastern Ethiopia. Journal of East African Natural History, 97(2):165-185.

Fekadu Gurmessa, Teshome Soromessa, and Ensermu Kelbessa, (2012). Structure and Regeneration status of Komto Afromontane Moist Forest, East Wellega Zone, West Ethiopia. Journal of Forestry Research, 23:205-216.

Gebremicael Fisaha, Kitessa. Hundera, and Gemedo Dalle. 2013. "Woody Plants'Diversity, Structural Analysis and Regeneration Status of Wof-Washa Natural Forest, North-east, Ethiopia."African Journal of Ecology, 51:599-608.

Gemedo, D.T., Maass, B.L. and Isselstein, J. (2006) Encroachment of woody plants and its impact on pastoral livestock production in the Borana Lowlands, Ethiopa. Afr. J. Ecol. 44:237-246.

Getachew Tesfaye, Demel Teketay and Masresha Fetene (2002). Regeneration of fourteen tree species in Harenna forest, southeastern Ethiopia. Flora, 197:461-474.

Getachew Tesfaye, Demel Teketay and Masresha Fetene and Beck, E. 2010."Regeneration of Seven Indigenous Tree Species in a Dry Afromontane Forest, Southern Ethiopia." Flora-Morphology, Distribution, Functional Ecology of Plants, 205:135-143.

Getachew Mulualem and Weldemariam Tesfahunegny, 2016. Review of Key Wildlife Threats Factors from Literature and Observation Perspectives: A Way forward for Sustainable Wildlife Genetic Resource Conservation Practices in Ethiopia. Journal of Zoology Studies, 3(5):01-12.

Getaneh Gebeyehu, Teshome Soromessa, Tesfaye Bekele \& Demel Teketay (2019): Species composition, stand structure, and regeneration status of tree species in dry Afromontane forests of Awi Zone, northwestern Ethiopia, Ecosystem Health and Sustainability, 17p.

Haile Adamu Wale, Tamrat Bekele, Gemedo Dalle (2012a). Floristic diversity, regeneration status and vegetation structure of woodlands in Metema area, Amhara National Regional State, North-western Ethiopia. Journal of Forestry Research, 23(3): 391-398.

Haile Yineger, Ensermu Kelbessa, Tamrat Bekele and Ermias Lulekal (2008). Floristic composition and structure of the dry Afromontane forest at Bale Mountains National Park, Ethiopia. SINET: Ethiop. J. Sci. 31(2):103-120. 
Haileab Zegeye, Demel Teketay and Ensermu Kelbessa (2011). Diversity and regeneration status of woody species in Tara Gedam and Abebaye forests, northwestern Ethiopia. Journal of Forestry Research, 22(3):315-328.

Haileab, Zegeye, Demel, Teketay, Kelbessa, Ensermu, 2005. Diversity, regeneration status and socioeconomic importance of the vegetation in the islands of Lake Ziway, South-central Ethiopia. Flora, $201,483 \mathrm{e} 498$.

Hasan Yusuf, Treydte, A. C., Sebsebe Demissew \& Zerihun Woldu, 2011. Assessment of woody species encroachment in the grasslands of Nechisar National Park, Ethiopia. Afr. J. Ecol., 49:397-409.

Hedberg, I. and Edwards, S. (1989). Flora of Ethiopia (Vol.3): Pittosporaceae to Araliaceae. Addis Ababa and Uppsala: The National Herbarium.732p.

Hedberg, I. and Hedberg, O. (2003). Apiaceae. In: Inga Hedberg, Sue Edwards and Sileshi Nemomissa, (eds). Flora of Ethiopia and Eritrea (vol.4.1): Apiaceae to Dipsacaceae. Addis Ababa and Uppsala:The National Herbarium.1-45p.

Hedberg, I., Ensermu Kelbessa, Edwards, S., Sebsebe Demissew, Persson, E. (2006). Flora of Ethiopia and Eritrea (vol.5):Gentianaceae to Cyclocheilaceae. Addis Ababa and Uppsala: The National Herbarium. 690p.

Hedberg, I., Friis I. and Persson, E. (2009a). Flora of Ethiopia and Eritrea (vol.1): Lycopodiaceae to Pinaceae. Addis Ababa and Uppsala, The National Herbarium. Pp. 305.

Hedberg, I., Friis I. and Persson, E. (2009b). Flora of Ethiopia and Eritrea. General Part and Index to Volumes 1-7(vol.8). Addis Ababa and Uppsala: The National Herbarium.331p.

Henle, K., Davies, K. F., Kleyer, M., Margules, C., \& Settele, J. (2004). Predictors of Spe-cies Sensitivity to Fragmentation. Biodiversity and Conservation,13:207-251.

Kedir Aliyi, Kitessa Hundera, and Gemedo Dalle, (2015). Floristic Composition, Vegetation Structure and Regeneration Status of Kimphe Lafa Natural Forest, Oromia Regional State, West Arsi, Ethiopia. Research \& Reviews: Journal of Life Sciences, 5(1):19-32.

Kent, M. and Coker, P. (1992). Vegetation description and analysis. A practical approach. Wiley, New York. 363p.

Kflay Gebrehiwot, and Kitessa Hundera, (2014). Species composition, Plant Community structure and Natural regeneration status of Belete Moist Evergreen Montane Forest, Oromia Regional state, Southwestern Ethiopia. Momona Ethiopian Journal of Science, 6(1):97-101.

Khumbongmayum, M.L., Khan, M.L \& Tripathi, R.S. 2006. Biodiversity conservation in sacred groves of Manipur, north-east India: Population structure and regeneration status of woody species. Biodiversity and Conservation, 15:2439-2456.

Kobe, R. K., and C. F. Vriesendorp. 2011. "Conspecific Density Dependence in Seedlings Varies with Species Shade Tolerance in a Wet Tropical Forest.” Ecology Letters, 14:503-510.

Krishnamurthy, Y.L. Prakasha, H.M. Nanda, A. Krishnappa, M. Dattaraja, H.S. Suresh, H.S. 2010. Vegetation structure and floristic composition of a tropical dry deciduous forest in Bhadra Wildlife Sanctuary, Karnataka, India. Tropical Ecology, 51(2):235-246.

Kuijper, D. P., J. P. Cromsigt, B. Jędrzejewska, S. Miścicki, M. Churski, W. Jędrzejewski, and I. Kweczlich. 2010."Bottom-up versus Top-down Control of Tree Regeneration in the Białowieża Primeval Forest, Poland."Journal of Ecology, 98:888-899.

Kumelachew Yeshitla and Tamrat Bekele,(2002). Plant community analysis and ecology of afromontane and transitional rainforest vegetation of Southwestern Ethiopia. SINET: Ethiop.J.Sci., 25 (2):155175.

Lamprecht, H. (1989). Silviculture in the Tropics: Tropical forest ecosystems and their tree species possibilities and methods for their long-term utilization. Federal Republic of Germany, Eschborn.

Leul Kidane, Tamrat Bekele and Sileshi Nemomissa,(2010). Vegetation Composition in HugumbirdaGratkhassu National Forest Priority Area, South Tigray. MEJS, 2(2):27-48.

Martin, G.J. (1995). Ethnobotany: a Methods Manual. Chapman and Hall, London, UK, 268p.

Malede Birhan\& Girma Gebreyes (2015). Review on Problems, Prospects and Economic Contribution of Wildlife Management and Ecotourism in Ethiopia. J. Veterinary Sci. Technol.,6:257. 
McIntosh, R.P. (1985). The background of ecology. Cambridge University Press, Cambridge, UK.

Mekuria Argaw, Demel Teketay and Olsson M. (1999). Soil seed flora, germination and regeneration pattern of woody species in an Acacia woodland of Rift Valley in Ethiopia. J.Arid Environment, 43:411-435.

Melkamu Terefe Asmare and Abdella Gure, 2019. Effect of exclosure on woody species diversity and population structure in comparison with adjacent open grazing land: the case of Jabi Tehnan district north western Ethiopia. Ecosystem Health and Sustainability, 5(1):98-109.

Mesfin Tadesse (2004). Asteraceae (Compositae).In: Hedberg I,Friis I,Edwards S,eds. Flora of Ethiopia and Eritrea (vol.4.2). Addis Ababa and Uppsala: The National Herbarium. 408p.

Mligo, C. (2015). The impact of livestock grazing on soil characteristics in Mount Kilimanjaro, Tanzania. Journal of Geoscience and Environment Protection, 3:24-37.

Molla Mekonnen, Kindeya Gebrehiwet, Emiru Birhane \& Sara Teweldeberhan, (2010). Impact of Interference on Species Diversity of Large Wild Mammals in Awash National Park, Ethiopia. Journal of the Drylands, 3(1):181-188.

Mueller-Dombois, D. and Ellenberg, H. (1974). Aims and methods of vegetation ecology. New York: John Wiley \& Sons.547p.

Mwavu, E.N and Witkowski, Ed. T.F. 2009. Population structure and regeneration of multiple-use tree species in a semi-deciduous African tropical rainforest: Implications for primate conservation. Forest Ecology and Management, 258: 840-849.

Nagamatsu, D., Kenji, S., \& Akiko, S. (2002). Seedling Establishment of Deciduous Trees in Various Topographic Positions. Journal of Vegetation Science, 13:35-44.

Norden, N., R. C. Mesquita, T. V. Bentos, R. L. Chazdon, and G. B. Williamson. 2011. "Contrasting Community Compensatory Trends in Alternative Successional Pathways in Central Amazonia." Oikos, 120:143-151.

Phillips, S (1995). Poaceae (Gramineae). In: Hedberg I. and Edwards S., Eds. Flora of Ethiopia and Eritrea. AddisAbaba, Ethiopia; Uppsala; Sweden.438p.

Pokhriyal. P., Uniyal, P., Chauhan, D.S. \& Todaria, N.P. (2010). Regeneration status of tree species in forest of Phakot and Pathri Rao watersheds in Garhwal Himalaya. Current Science, 98:171-174.

Premavani, D., NAIDU, M.T., Venkaiah, M., 2014. Tree species diversity and population structure in the tropical forests of north central Eastern Ghats, India. Not. Sci. Biol. 6 (4),448e453.

Samson Shimelse, Tamrat Bekele and Alemayehu Mengistu, (2010). Floristic Diversity and Structure of Nechisar National Park, Ethiopia. Journal of the drylands, 3(1):165-180.

Sarkar, M. \& Devi, A. (2014). Assessment of diversity, population structure and regeneration status of tree species in Hollongapar Gibbon Wildlife Sanctuary, Assam, Northeast India. Tropical Plant Research, 1(2):26-36.

Saxena, A. K., \& Singh, J. S. (1984). Tree Population Structure of Certain Himalayan For-est Associations and Implications Concerning Their Future Composition. Vegetation,58:61-69.

Schulz, B.K., Bechtold, W.A. and Zarnoch, S.J. (2009). Sampling and estimation procedures for the vegetation diversity and structure indicator. General Technical Report PNW-GTR-781.United States Department of Agriculture, Forest Service.2p.

Sharma, V., and Chaudhry, S. 2018. "Vegetation Composition and Plant Diversity in Mining Disturbed Tropical Thorn Forest of Asola-Bhatti Wildlife Sanctuary, Northern India.”Taiwania, 63(3):267280.

Simon Shibru, \& Girma Balcha, (2004). Composition, Structure and Regeneration Status of Woody Plant Species in Dindin Natural Forest, Southeast Ethiopia: An Implication for Conservation. Ethiopian Journal of Biological Science, 3:15-55.

Swamy, P.S. 2000. Plant species diversity and tree population structure of a humid tropical forest in Tamil Nadu, India. Biodiversity and Conservation, 9:1643-1669.

Tamrat Bekele, (1993). Vegetation Ecology of Remnant Afromonten Forests on the Central Plateau of Shewa, Ethiopia. Acta Phytogeographica Suecica, 79:1-59. 
Tamrat Bekele, (1994). Phyosociology and Ecology of Humid Afromontane Forest on the Cen-tral Plateau of Ethiopia. Journal of Vegetation Science, 5:87-98.

Temesgen, Mekonen, Ayele Belayneh, Ashagrie Yeshanew,2015. Woody plant species diversity, structure and regeneration status of Woynwuha natural forest, North West Ethiopia. Asian J. Ethno Pharmacol. Med. Foods, 01(01):3e15.

Tesfay Atsbha, Anteneh Belayneh Desta,Tessema Zewdu. (2019). Woody species diversity, population structure, and regeneration status in the Grat-Kahsu natural vegetation, southern Tigray of Ethiopia. Heliyon, 5:e01120,25p.

Tesfaye Bogale, Demeke Datiko, Shiferaw Belachew, (2017b). Structure and Natural Regeneration Status of Woody Plants of Berbere Afromontane Moist Forest, Bale Zone, South East Ethiopia; Implication to Biodiversity Conservation. Open Journal of Forestry, 7:352-371.

Tesfaye Burju, Kitessa Hundera \& Ensermu Kelbessa, (2013). Floristic Composition and Structural Analysis of Jibat Humid Afromontane Forest, West Shewa Zone, Oromia National Regional State, Ethiopia. Ethiopian Journal of Education and Science, 8(2):11-33.

Tiwari, G. P. K., Tadele, K., Aramde, F. and Tiwari, S. C. (2010). "Community structure and regeneration potential of shorearobusta forest in subtropical sub-montane zone of Garhwal Himalaya,India. "Nature and Science, 8:70-74.

Tripathi, R. S., \& Khan, M. L. (2007). Regeneration Dynamics of Natural Forests. A Review, Proceedings of the Indian. National Science Academy, 73:167-195.

WCMC (1994) Biodiversity Data Sourcebook. World Conservation Monitoring Centre, World Conservation Press, Cambridge.

Yalden, D. and Largen, M. (1992) Endemic Mammals of Ethiopia. Mammal Review, 22:115-150.

Appendix 1: Natural regeneration status of woody species in KSNP (MD = Mature density, $\mathrm{SD}=$ Seedling density $\left(\right.$ Stem $\left.\mathrm{ha}^{-1}\right)$ and $\mathrm{SPD}=$ Sapling density; regeneration status $(\mathrm{RS})(\mathrm{G}=$ Good, $\mathrm{F}=$ Fair, and $\mathrm{P}=$ Poor) and $\mathrm{N}=$ None regenerating

\begin{tabular}{|l|l|l|r|r|r|l|}
\hline \multicolumn{1}{|c|}{ Scientific name (Species) } & Family & Habit & SD & SPD & MD & RS \\
\hline Acacia albida Del. & Fabaceace & tree & 0 & 0 & 0.31 & None \\
\hline Acacia etbaica Schweinf & Fabaceae & tree & 0 & 0 & 0.78 & None \\
\hline Acacia lahai Steud. \& Hochst.ex Benth. & Fabaceae & tree & 0 & 0 & 0.94 & None \\
\hline Acacia mellifera (Vahl) Benth. & Fabaceae & tree & 2.2 & 3.8 & 69.7 & Fair \\
\hline Acacia oerforta (Forssk.) Schweinf. & Fabaceae & shrub & 0.9 & 3 & 26.4 & Fair \\
\hline Acacia polyacantha Willd. & Fabaceae & tree & 0.8 & 1.6 & 7.19 & Fair \\
\hline Acacia senegal (L.) Willd. & Fabaceae & tree & 0.5 & 3.8 & 24.8 & Fair \\
\hline Acacia seyal Del. & Fabaceae & tree & 0 & 0.9 & 5.31 & Poor \\
\hline Acacia sp. Mart & Fabaceae & tree & 0 & 0 & 1.72 & None \\
\hline Acacia tortilis (Forssk.) Hayne. & Fabaceae & tree & 0 & 0 & 1.25 & None \\
\hline Adansonia digitata (L.) & Bombacaceae & tree & 0 & 0 & 4.22 & None \\
\hline Anogeissus leiocarpus (DC.) Guill. \& Perr. & Combretaceae & tree & 0 & 0 & 11.1 & None \\
\hline Balanites aegyptiaca (L.) Del. & Balanitaceae & tree & 1.1 & 7.7 & 29.4 & Fair \\
\hline Boscia angustifolia var. angustifolia A. Rich. & Capparaceae & tree/ shrub & 0 & 0 & 1.09 & None \\
\hline Boswellia papyrifera Hochst. ex A. & Burseraceae & tree & 0.6 & 1.7 & 27.8 & Fair \\
\hline Brucea antidysentrica J.F. & Simaroubacea & tree & 0 & 0 & 0.47 & None \\
\hline Buddleja polystachya Fresen. & Loganiaceae & Shrub & 0 & 0 & 0.31 & None \\
\hline Burkea africana Hook. & Caesalpiniaceae & tree & 0 & 0 & 3.28 & None \\
\hline Cadaba farinosa Forssk. & Capparaceae & shrub & 0 & 0 & 0.94 & None \\
\hline Calotropis procera (Aiton) W.T.Aiton. & Asclepiadaceae & tree & 0 & 0 & 2.19 & None \\
\hline Capparis decidua (Forssk.) Edgew. & Capparaceae & tree & 0 & 0 & 0.63 & None \\
\hline Carissa edulis (Forssk.) Vahl. & Apocynaceae & shrub & 0 & 0 & 1.72 & None \\
\hline Casuarina equisetifolia (L.) & Casuarinaceae & tree & 1.1 & 4.2 & 10.8 & Fair \\
\hline
\end{tabular}




\begin{tabular}{|c|c|c|c|c|c|c|}
\hline Scientific name (Species) & Family & Habit & SD & SPD & MD & $\mathbf{R S}$ \\
\hline Combretum glutinosum Perr. ex DC. & Combretaceae & shrub & 0 & 0 & 4.22 & None \\
\hline Combretum hartmannianum Schweinf. & Combretaceae & tree & 0.3 & 3.3 & 53.4 & Fair \\
\hline Combretum molle R. Br. ex G. Don. & Combretaceae & tree & 0 & 0.8 & 18.3 & Poor \\
\hline Combretum sp. Loefl. & Combretaceae & tree & 0 & 0 & 4.22 & None \\
\hline Commiphora boranensis K. Vollesen. & Burseraceae & tree & 0 & 0 & 5 & None \\
\hline Dalbergia melanoxylon Guill. \& Perr. & Fabaceae & tree & 0 & 0.3 & 7.19 & Poor \\
\hline Dicrostachys cinerea (L.)Wight and Arn. & Fabaceae & tree & 0.3 & 6.4 & 22.3 & Fair \\
\hline Diospyros abyssinica (Hiern) F. White & Ebenaceae & tree & 0 & 0 & 2.19 & None \\
\hline Diospyros mespiliformis Hochst. ex A. DC. & Ebenaceae & tree & 0 & 0 & 4.69 & None \\
\hline Feretia apodanthera Delile. & Rubiaceae & shrub & 0 & 0 & 0.47 & None \\
\hline Ficus sycomorus (L.) & Moraceae & tree & 0 & 0 & 0.31 & None \\
\hline Grewia bicolor Juss. & Tiliaceae & tree/ shrub & 0 & 0 & 4.84 & None \\
\hline Grewia flavescens Juss. & Tiliaceae & tree / shrub & 0 & 0 & 2.03 & None \\
\hline Grewia mollis Juss. & Tiliaceae & tree & 0 & 0 & 0.63 & None \\
\hline Grewia villosa Willd. & Tiliaceae & shrub & 0 & 0.5 & 1.72 & Poor \\
\hline Hyphaene thebaica (L.) Mart. & Arecaceae & tree & 1.4 & 7.8 & 15 & Fair \\
\hline Jasminum abyssinicum Hochst. ex DC. & Oleaceae & shrub & 0 & 0 & 1.25 & None \\
\hline Lannea microcarpa Engl. \& K. Krause. & Anacardiaceae & tree & 0 & 0 & 3.59 & None \\
\hline Leptadenia lanceolata (Poir.) Goyder. & Asclepiadaceae & shrub & 0 & 0 & 0.47 & None \\
\hline Maytenus senegallensis Forssk. & Celastraceae & tree & 0 & 0 & 0.94 & None \\
\hline Melia azedarach (L.) & Meliaceae & tree & 0 & 0 & 0.47 & None \\
\hline Moringa stenopetala (Baker f.) Cufod. & Moringaceae & tree & 0 & 0 & 0.63 & None \\
\hline Nerium oleander (L.) & Apocynaceae & shrub & 0 & 0 & 0.47 & None \\
\hline Otostegia ellenbeckii Gurke. & Lamiaceae & shrub & 0 & 0 & 0.31 & None \\
\hline Parkinsonia aculeata (L.) & Fabaceae & tree & 0 & 0 & 0.16 & None \\
\hline Pittosporum viridiflorum Sims. & Pittosporaceae & tree & 0 & 0 & 2.66 & None \\
\hline Plumbago zeylanica (L.) & Plumbaginace & shrub & 0 & 0.2 & 0.78 & Poor \\
\hline Ricinus communis (L.) & Euphorbiaceae & shrub & 0 & 0 & 0.63 & None \\
\hline Salvadora persica (L.) & Salvadoraceae & shrub & 0 & 0 & 0.78 & None \\
\hline Sclerocarya birrea (A. Rich.) Hochst. & Anacardiaceae & tree & 0 & 0 & 2.34 & None \\
\hline Senna sinqueana (Delile) Lock. & Fabaceae & shrub & 0 & 0 & 0.16 & None \\
\hline Solanum incanum (L.) & Solanaceae & shrub & 0 & 0 & 1.09 & None \\
\hline Sterculia africana Del. & Sterculiaceae & tree & 0 & 0 & 6.56 & None \\
\hline Stereospermum kunthianum Cham. & Bignoniaceae & tree/ shrub & 0 & 0 & 3.28 & None \\
\hline Tamarindus indica (L.) & Fabaceae & tree & 0 & 0 & 9.22 & None \\
\hline Terminalia brownii Fresen. & Combretaceae & tree & 0.2 & 0.3 & 32 & Fair \\
\hline Terminalia laxiflora Engl. \& Diels. & Combretaceae & tree & 0 & 0 & 1.56 & None \\
\hline Terminalia sp.L. & Combretaceae & tree & 0 & 0 & 1.09 & None \\
\hline Ziziphus тисronata Willd. & Rhamnaceae & tree / shrub & 0 & 0 & 2.66 & None \\
\hline Ziziphus spina-christi (L.) Desf. & Rhamnaceae & tree & 1.3 & 2.3 & 13.6 & Fair \\
\hline Ziziphus mauritiana Willd. & Rhamnaceae & tree/shrub & 0 & 0 & 0.63 & None \\
\hline Carica papaya (L.)* & Caricaceae & tree* & - & - & - & - \\
\hline Citrus aurantifolia (Christm.) Swingle* & Rutaceae & shrub* & - & - & - & - \\
\hline Mangifera indica (L.)* & Anacardiaceae & tree* & - & - & - & - \\
\hline Rhamnus prinoides L'Hér.* & Rhamnaceae & shrub* & - & - & - & - \\
\hline Cordia Africana Lam.* & Boraginaceae & tree* & - & - & - & - \\
\hline Delonix regia (Boj. ex Hook.) Raf.* & Fabaceae & tree* & - & - & - & - \\
\hline Total & - & - & 10.7 & 48.6 & 466 & - \\
\hline
\end{tabular}

Note: * Plant species recorded outside quadrat area 